\title{
QUANTITY OF PHOSPHOROUS MOBILIZING BACTERIA IN THE ROOT ZONE OF WHEAT UNDER THE INFLUENCE POLYMYXOBACTERYN AND FERTILIZERS
}

Kovpak P. V., Tokmakova L. M., Larchenko I. V., Trepach A. O.

Institute of Agricultural Microbiology and Agricultural Production NAAS

97, Shevchenko Str., Chernihiv, 14027, Ukraine

E-mail: tokmakova_ln@mail.ru

The paper presents the results of studies of the impact of microbial preparation Polymyxobacteryn and different doses of mineral fertilizers on the development of phosphorous mobilizing bacteria in rhizosphere soil of winter wheat plants (Sonechko variety). It was shown that quantity phosphorous mobilizing bacteria increases under the influence of bacterization and fertilizers in doses not exceeding $N_{60} P_{60} K_{60}$.

Keywords: mineral fertilizers, Polymyxobacteryn, winter wheat, phosphorous mobilizing bacteria.

Phosphate nutrition plays an important role in yield formation of agricultural crops, including wheat [1]. Due to the inaccessibility of certain forms of phosphorus for plants their growth and productivity is often limited by the presence of water-soluble phosphorus compounds [2]. Therefore, the problem of increasing the availability of phosphorus for cultured crops from fertilizers and soil requires attention of scientists. Utilization of techniques and methods capable to enhance activity of soil microorganisms, which play major role in the transformation of phosphorus compounds of soil and fertilizers, is one of the solutions. Due to the high reproduction rates bacteria is involved in the biological cycle of many elements, including phosphorus $[3,4]$.

Application of microbial preparations basing on microorganisms capable of metabolic conversion of soluble soil phosphate in soluble forms is one of the effective measures to enhance the development of phosphorous mobilizing bacteria in soils of agrocenosis [5-7]. In addition to improvement of phosphorus nutrition of bacterized plants, microbial preparations stimulate growth of other members of certain ecological and trophic groups of microorganisms in rhizosphere soil that indirectly indicates on the positive metabolic changes in plants $[8,9]$. However, the effectiveness of the introduction of active strain - biological agent of preparation and its influence on the microbial associations in root areas of bacterized plants depends on fertilizers background. In this context, the aim of our study was to investigate the quantity of phosphorous mobilizing bacteria in the rhizosphere of winter wheat plants treated with Polymyxobacteryn and different doses of mineral fertilizers.

Materials and methods. The study was conducted during the 2011-2012 years on winter wheat (Sonechko variety) in stationary field experiment in the Institute of Agricultural Microbiology and Agricultural Production NAAS on meadow-chernozem soils containing $2.12 \%$ humus, $95.2 \mathrm{mg} / \mathrm{kg}$ of easily hydrolyzed nitrogen, $226 \mathrm{mg} / \mathrm{kg}$ of phosphorus, $108 \mathrm{mg} / \mathrm{kg}$ of exchangeable potassium, $\mathrm{pH}_{\text {salt }}-5.30$. The following variants were included into the experiment scheme: 1 - without fertilizer (control), $2-\mathrm{N}_{30} \mathrm{P}_{30} \mathrm{~K}_{30}$ $\left(\mathrm{N}_{20}\right.$ in autumn $+\mathrm{N}_{10}$ at tillering stage), $3-\mathrm{N}_{60} \mathrm{P}_{60} \mathrm{~K}_{60}\left(\mathrm{~N}_{20}\right.$ in autumn $+\mathrm{N}_{40}$ at tillering 
stage), $4-\mathrm{N}_{90} \mathrm{P}_{90} \mathrm{~K}_{90}\left(\mathrm{~N}_{20}\right.$ in autumn $+\mathrm{N}_{40}$ at tillering stage $+\mathrm{N}_{30}$ at booting stage), $5-8-$ same variants combined with bacterization. Research plots area was 86.4 sq.m $(7.2 \mathrm{~m} \mathrm{x}$ $12.0 \mathrm{~m}$ ), repetition of the experiment - four-fold. Winter wheat farming techniques common to the Polissya region. Pre-sowing seeds treatment was performed in accordance to the SOU 01.11-37-782:2008 [10].

Samples of rhizosphere soil were taken for microbiological analysis during following phases of wheat plants development: booting, flowering and milky ripeness. Reckoning of bacteria number capable to dissolve mineral and organic phosphorus compounds was performed on agar nutrient medium of Muromtsev with the addition of tricalcium phosphate or calcium phosphoglycerol [11]. Field experiments and mathematical analysis of results were performed according to the conventional methods [12].

Results and discussion. The results obtained in 2011 have shown that the growth of microorganisms that dissolve mineral forms of phosphate in the rhizosphere soil of wheat plants depends on fertilizers background. Analysis of dependence found have shown its parabolic nature. Application of low fertilizers doses have stimulated the growth of studied microorganisms. Use of fertilizer doses over $\mathrm{N}_{60} \mathrm{P}_{60} \mathrm{~K}_{60}$ have reduced the number phosphorous mobilizing bacteria. On the contrary, pre-sowing seeds bacterization with Polymyxobacteryn have increased population of wheat plants rhizosphere soil bacteria. Most likely, the quantity of bacteria have increased due to the development of the introduced bacterial strain and effect of microbial preparation on plants growth, intensification of photosynthesis and provision of root zone microbial communities with plant assimilates. Under the bacterization conditions the development of bacteria was also of parabolic nature and have clearly depended on fertilizers background (Fig. 1). Optimal for the growth of the microorganisms of the studied group were $\mathrm{N}_{30} \mathrm{P}_{30} \mathrm{~K}_{30}$ and $\mathrm{N}_{60} \mathrm{P}_{60} \mathrm{~K}_{60}$ doses of fertilizer. Excess levels of mineral fertilizers in the experiment have decreased the number of bacteria that dissolve mineral phosphates as comparing to the above mentioned fertilizers background.

Data received in 2012 have generally confirmed the results of the fertilizers backgrounds influence separately and in combination with pre-sowing seeds treatment with microbial preparation on formation of microorganisms associations of studied groups (Fig. 2).

Thus, these results obtained indicate that the optimum conditions for growth of microorganisms that dissolve mineral forms of phosphate in the root zone of plants winter wheat is a fertilizer application in doses not exceeding $\mathrm{N}_{60} \mathrm{P}_{60} \mathrm{~K}_{60}$. Increased doses of fertilizer reduces the number of bacteria that dissolve mineral phosphates. 
FIGURE 1. Effect of bacterization and fertilizers on the quantity of bacteria that dissolve mineral forms of phosphate in the rhizosphere soil of winter wheat plants (Sonechko variety, meadow-chernozem soils, 2011).

$\square$ W/o inoculation $\mathbb{8}$ Polymyxobacteryn

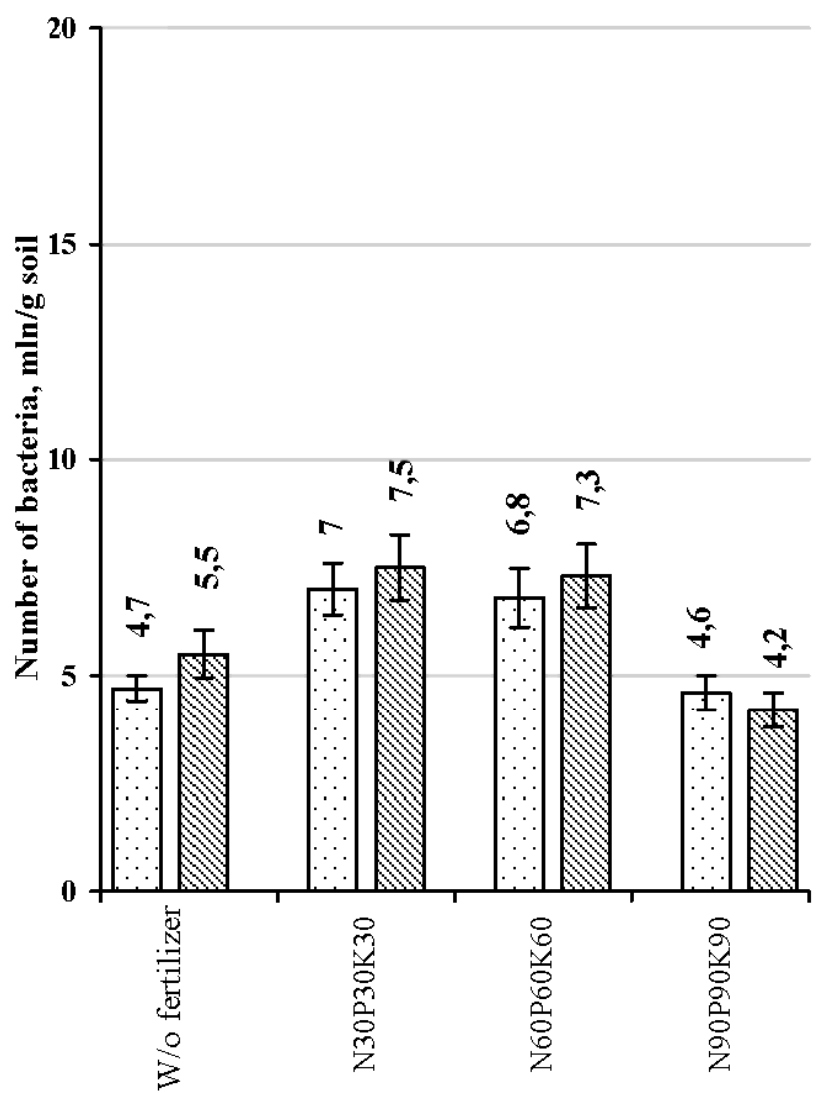

Booting stage $\square$ W/o inoculation $\mathbb{Q}$ Polymyxobacteryn

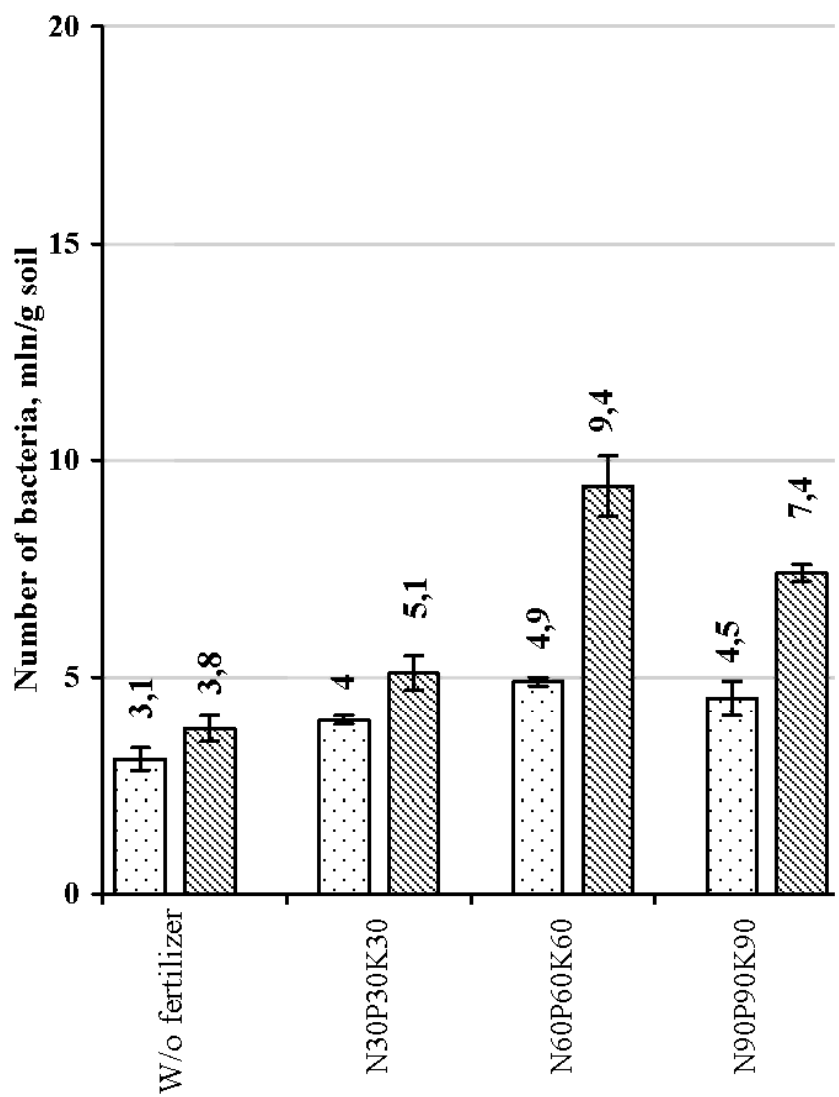

Flowering stage $\square$ W/o inoculation $\mathbb{Q}$ Polymyxobacteryn

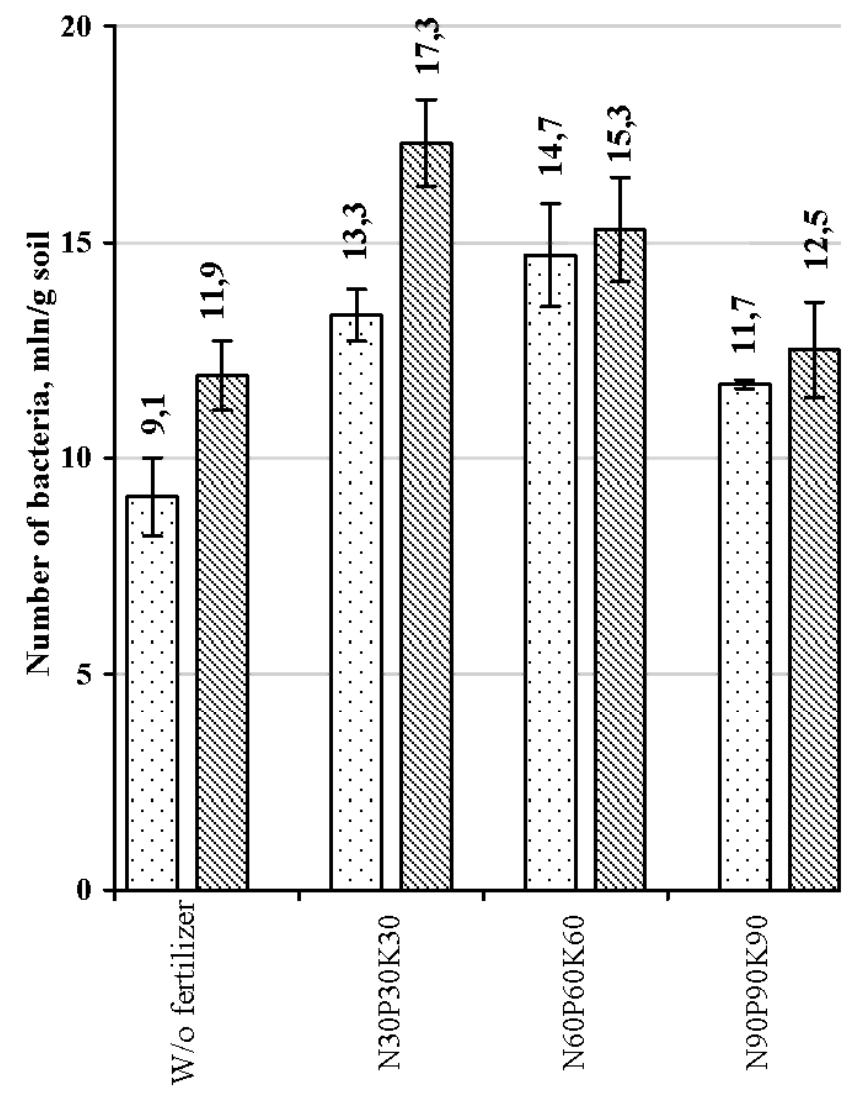

Milky ripeness stage 
FIGURE 2. Effect of bacterization and fertilizers on the quantity of bacteria that dissolve mineral forms of phosphate in the rhizosphere soil of winter wheat plants (Sonechko variety, meadow-chernozem soils, 2012).

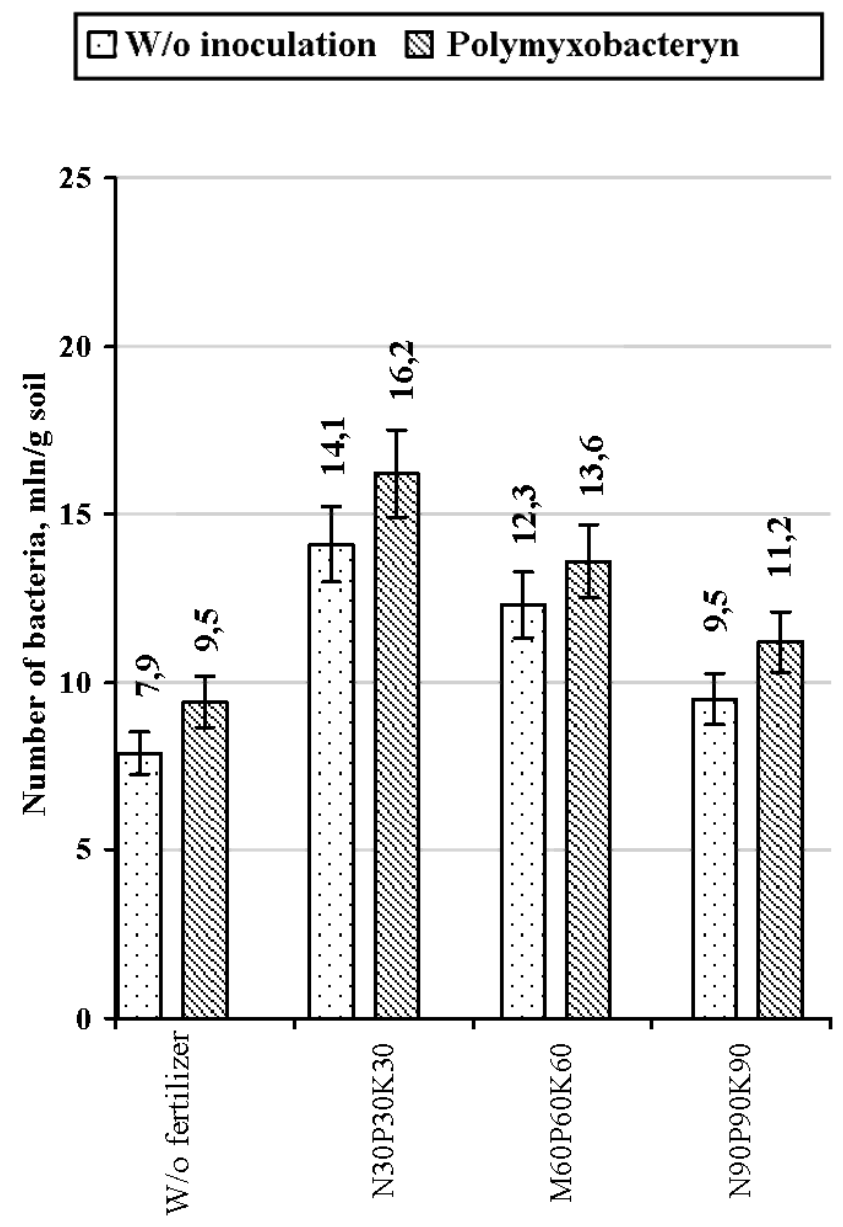

Booting stage

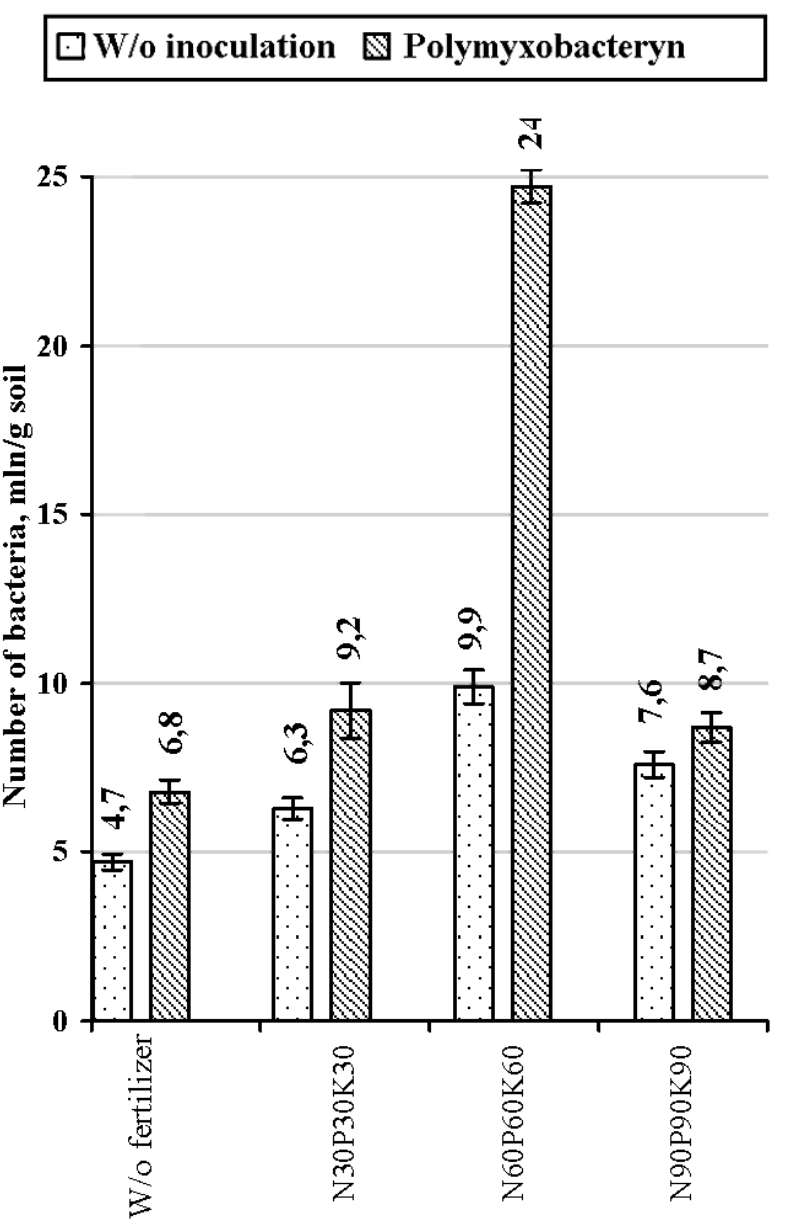

Flowering stage

\section{$\square$ W/o inoculation $\mathbb{\text { Solymyxobacteryn }}$}

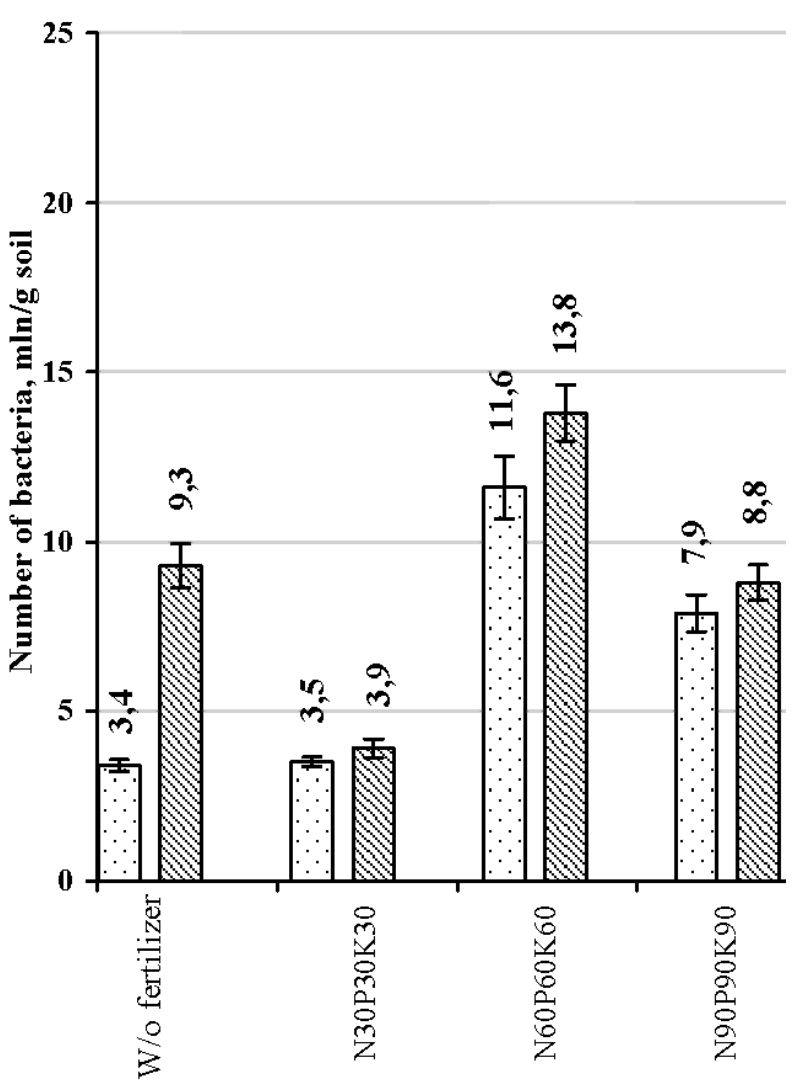

Milky ripeness stage 
Reckoning results of bacteria which hydrolyze organic forms of phosphate, have showed some differences from the above described group of microorganisms under the influence of fertilizers and Polymyxobacteryn. Thus, the data obtained in 2011 have shown that the optimal conditions for the development of these bacteria in the rhizosphere of wheat plants during the booting stage was the average dose of fertilizer $\left(\mathrm{N}_{60} \mathrm{P}_{60} \mathrm{~K}_{60}\right)$, while bacterization on this background has also shown the biggest values by this parameter -12.0 million / g soil. A similar situation was observed during the flowering stage - the number of bacteria in plants root zone on $\mathrm{N}_{60} \mathrm{P}_{60} \mathrm{~K}$ background is 13.9 million $/ \mathrm{g}$ soil, while treatment with Polymyxobacteryn have increased this number to $21.7 \mathrm{million} / \mathrm{g}$ soil. During milk ripeness stage, almost all variants with Polymyxobacteryn bacterization have decreased number of this group of microorganisms, which is probably due to the impoverishment of organic phosphorus in the root zone of winter wheat plants (Fig. 3).

The results obtained in 2012 have shown that the quantity of bacteria that hydrolyze organic forms of phosphate has increased at application of microbial preparation Polymyxobacteryn on all fertilizer backgrounds. The best result was noticed at the combined use of Polymyxobacteryn and fertilizer in dose of $\mathrm{N}_{60} \mathrm{P}_{60} \mathrm{~K}_{60}$. During booting stage the number of bacteria on $\mathrm{N}_{60} \mathrm{P}_{60} \mathrm{~K}_{60}$ background was $12.5 \mathrm{~m} / \mathrm{g}$ soil, while in variants with Polymyxobacteryn - $15.0 \mathrm{million} / \mathrm{g}$ soil. At next stage the number of microorganisms has increased from 11.2 million/g soil (on $\mathrm{N}_{60} \mathrm{P}_{60} \mathrm{~K}_{60}$ background) to 22.3 million/g soil (microbial preparation) (Fig. 4).

Thus, the use of fertilizers in doses that not exceed $\mathrm{N}_{60} \mathrm{P}_{60} \mathrm{~K}_{60}$ in cultivation of winter wheat plants has a positive effect on the quantity of bacteria that hydrolyze organic forms of phosphate. It was established that Polymyxobacteryn application in combination with mineral fertilizers in doses $\mathrm{N}_{60} \mathrm{P}_{60} \mathrm{~K}_{60}$ created the best conditions for the development of phosphorous mobilizing microorganisms.

Therefore, it was shown that intermittent dosing of fertilizer in low doses creates the best conditions formation of phosphorous mobilizing microorganisms in the rhizosphere of winter wheat plants. Application of microbial preparation Polymyxobacteryn has a significantly increased the number of bacteria that dissolve both mineral and organic forms of phosphate in the rhizosphere of winter wheat plants, especially on the $\mathrm{N}_{60} \mathrm{P}_{60} \mathrm{~K}_{60}$ background. 
FIGURE 3. Effect of bacterization and fertilizers on the quantity of bacteria that hydrolyze organic forms of phosphate in the rhizosphere soil of winter wheat plants (Sonechko variety, meadow-chernozem soils, 2011).

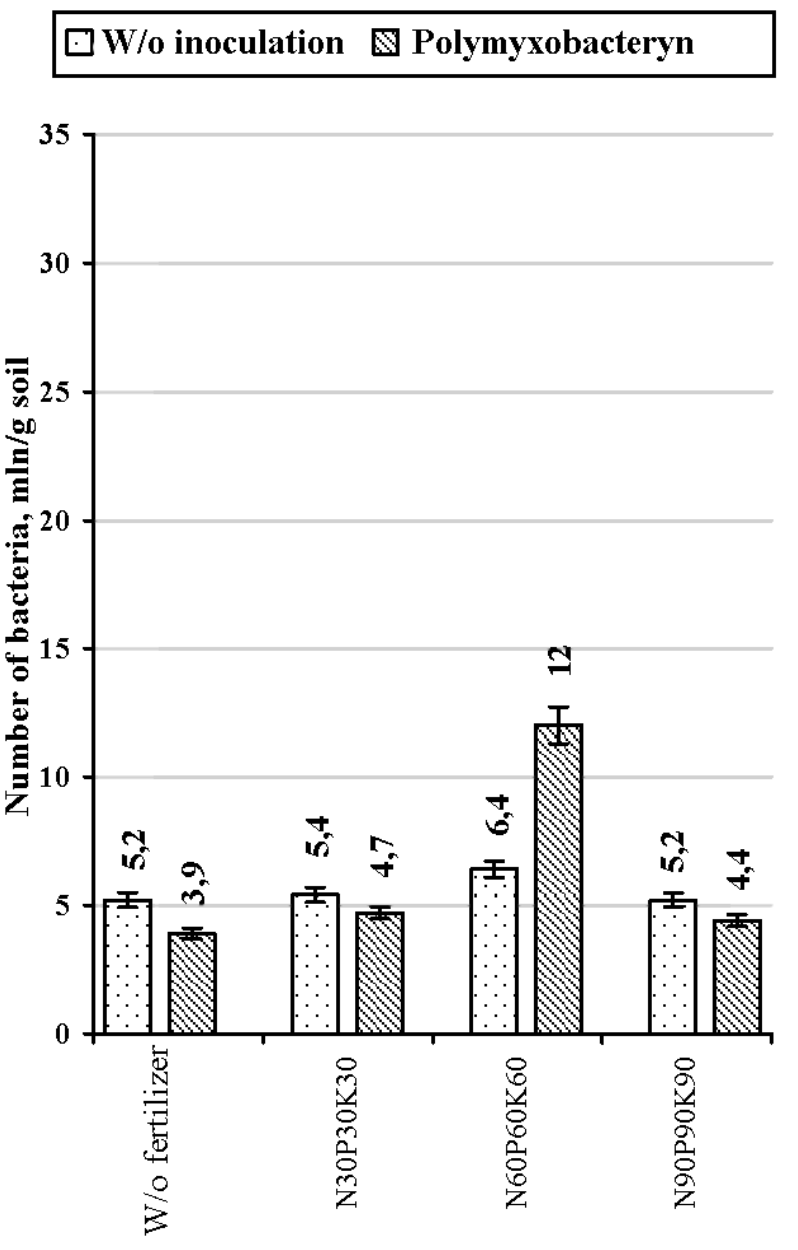

Booting stage

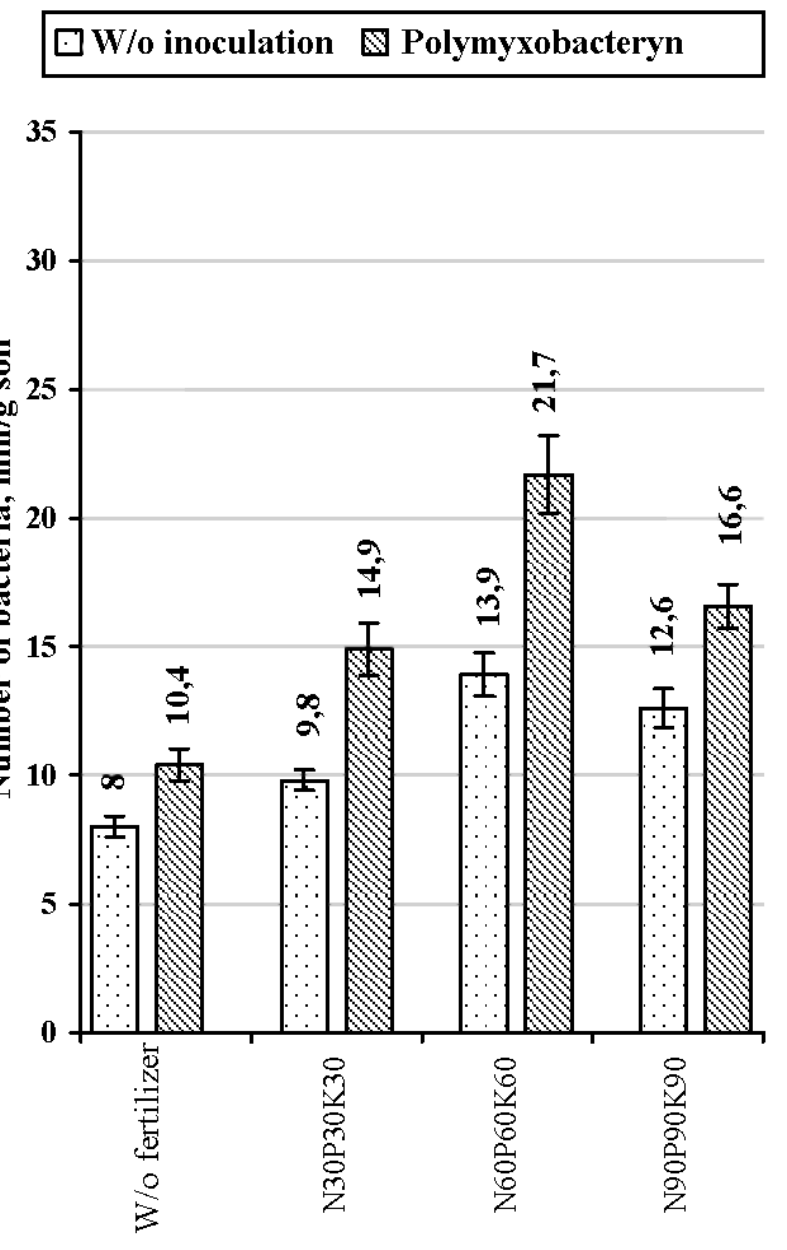

Flowering stage

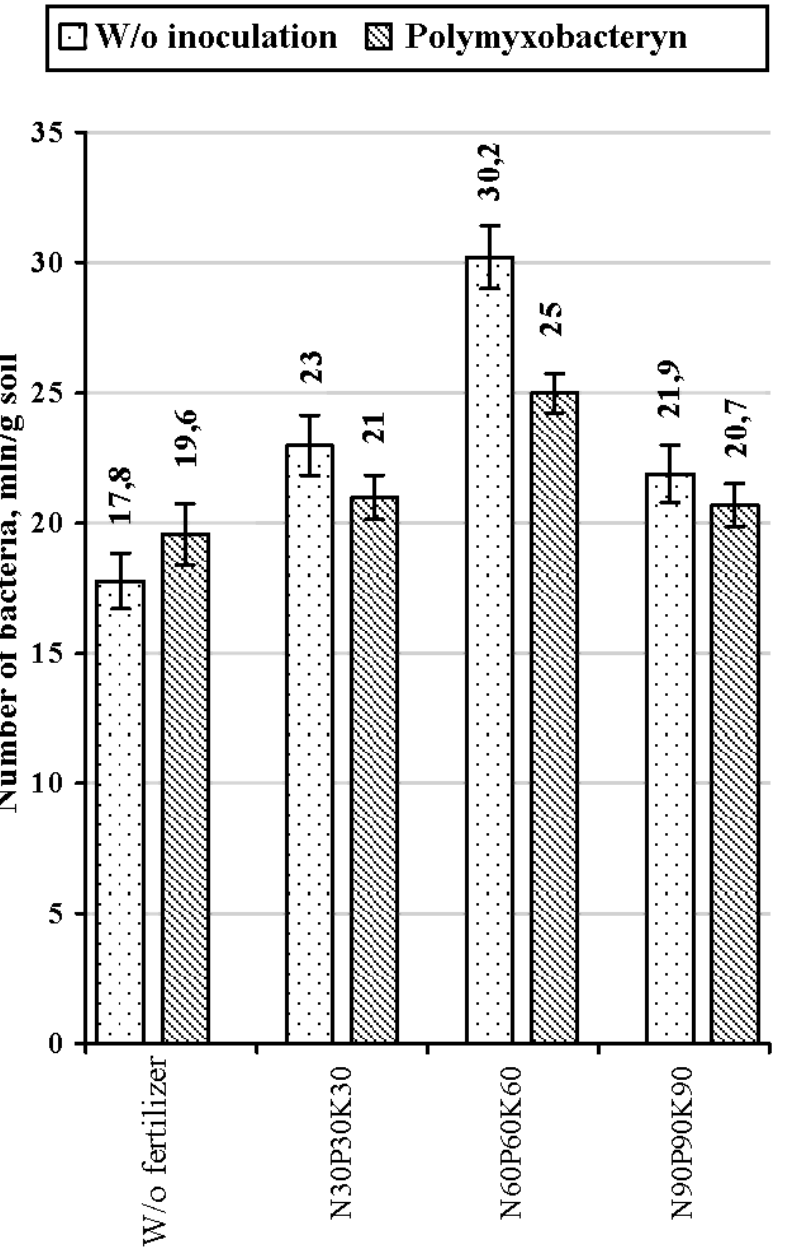

Milky ripeness stage 
FIGURE 4. Effect of bacterization and fertilizers on the quantity of bacteria that hydrolyze organic forms of phosphate in the rhizosphere soil of winter wheat plants (Sonechko variety, meadow-chernozem soils, 2012).

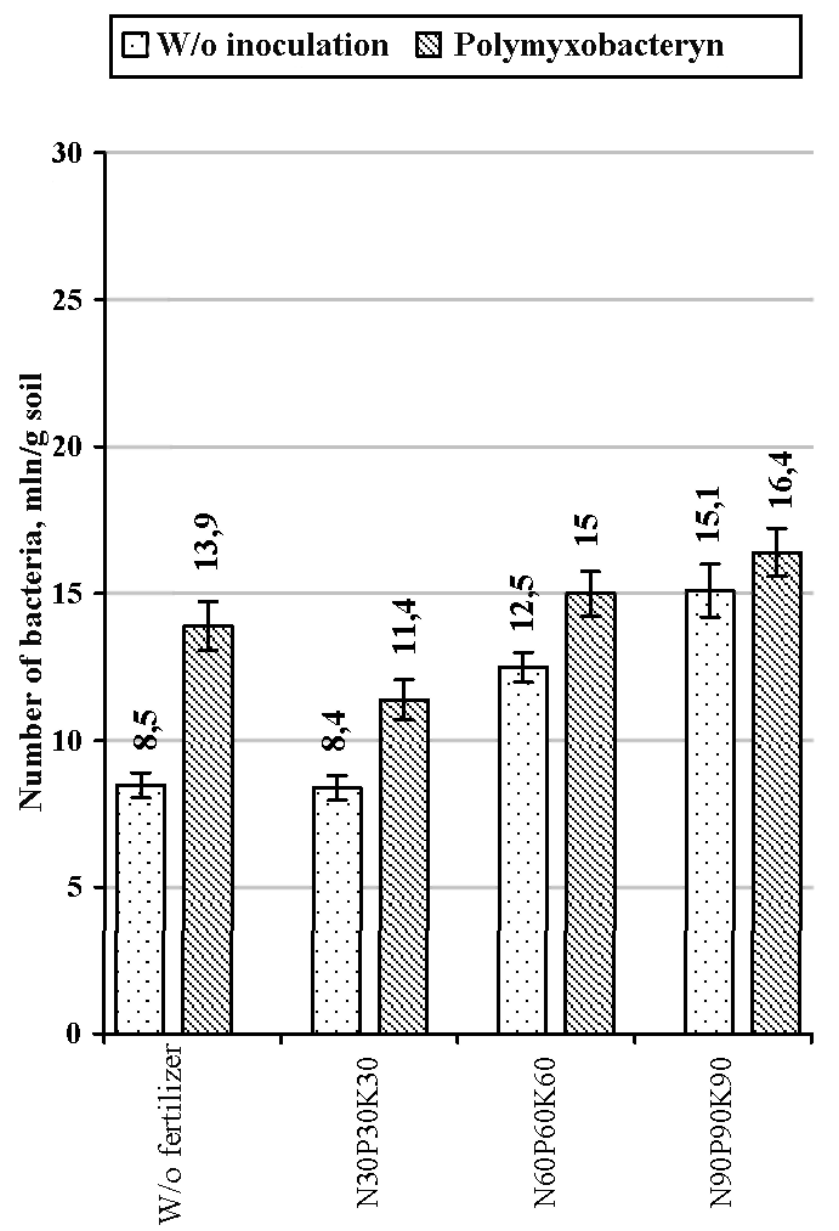

Booting stage

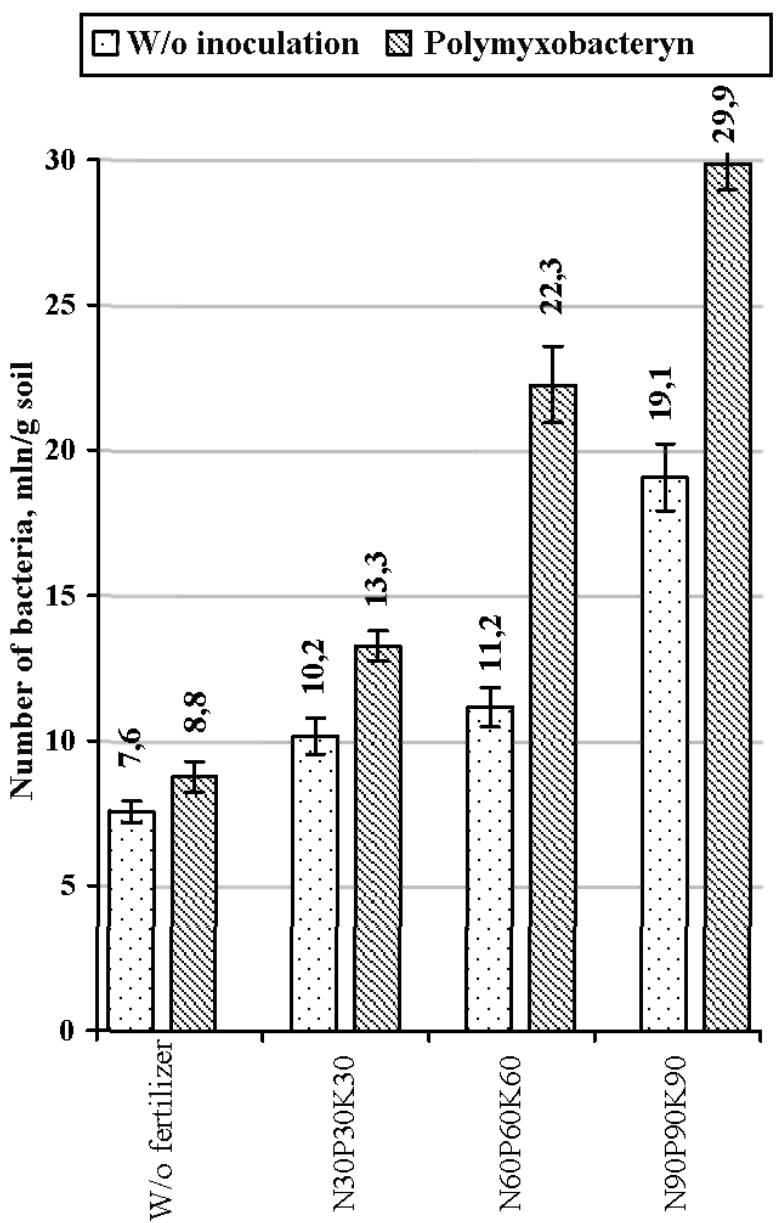

Flowering stage $\square$ W/o inoculation $\$$ Polymyxobacteryn

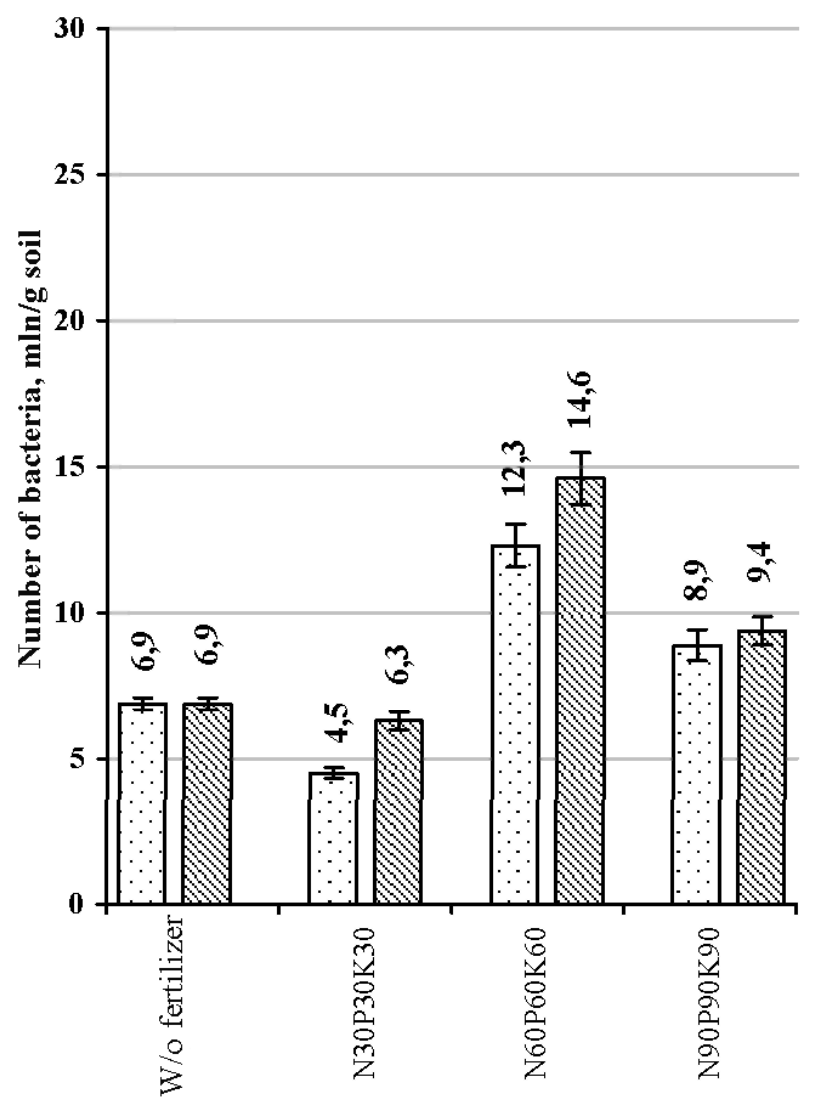

Milky ripeness stage 